\title{
Potency of probiotics Bifidobacterium spp. and Lactobacillus casei to improve growth performance and business analysis in organic laying hens
}

Widya Paramita Lokapirnasari,1,2, Teguh Bagus Pribadi ${ }^{3}$, Anam Al Arif ${ }^{1}$, Soeharsono Soeharsono ${ }^{4}$, Sri Hidanah ${ }^{1}$, Nenny Harijani ${ }^{5}$, Rifqy Najwan ${ }^{3}$, Khoirul Huda ${ }^{3}$, Hana Cipka Pramuda Wardhani ${ }^{3}$, Nabil Fariz Noor Rahman ${ }^{3}$ and Andreas Berny Yulianto 6

1. Department of Animal Husbandry, Faculty of Veterinary Medicine, Universitas Airlangga, Jl. Mulyorejo, Kampus C, Universitas Airlangga, Surabaya, Indonesia; 2. Halal Research Center, Universitas Airlangga, Jl. Mulyorejo, Kampus C, Universitas Airlangga, Surabaya, Indonesia; 3. Magister of Veterinary Agribusiness, Faculty of Veterinary Medicine, Universitas Airlangga, Indonesia; 4. Department of Veterinary Anatomy, Faculty of Veterinary Medicine, Universitas Airlangga, Indonesia; 5. Department of Veterinary Public Health, Faculty of Veterinary Medicine, Universitas Airlangga, Indonesia; 6. Sains Veteriner, Faculty of Veterinary Medicine, Universitas Airlangga, Surabaya, Indonesia. Corresponding author: Widya Paramita Lokapirnasari, e-mail: widyaparamitalokapirnasari@gmail.com Co-authors: TBP: teguhbaguspribadi@gmail.com, AA: a_alarif@yahoo.com, SS: 1961suharsono@gmail.com, SH: s_hidanah@yahoo.com, NH: nennyharijani@yahoo.co.id, RÑ : rifqinajwan28@gmail.com, KH: khoirulh779@gmail.com, HCPW: hanamoci@gmail.com, NFNR: rahman_nabil@yahoo.co.id, ABY: bernyjuliantomiroen@gmail.com Received: 16-02-2019, Accepted: 13-05-2019, Published online: 21-06-2019

doi: 10.14202/vetworld.2019.860-867 How to cite this article: Lokapirnasari WP, Pribadi TB, Al Arif A, Soeharsono S, Hidanah S, Harijani N, Najwan R, Huda K, Wardhani HCP, Rahman NFN, Yulianto AB (2019) Potency of probiotics Bifidobacterium spp. and Lactobacillus casei to improve growth performance and business analysis in organic laying hens, Veterinary World, 12(6): 860-867.

\begin{abstract}
Aim: This study aimed to determine the use of probiotics Bifidobacterium spp. and Lactobacillus casei as alternative antibiotic growth promoters (AGPs) to improve growth performance and business analysis.

Materials and Methods: This study used a completely randomized factorial design. The first factor was the time of administration $(1,2,3$, and 4 weeks) and the second was the use of probiotics (control without probiotics; $0.1 \%$ AGP and $0.5 \%$ Bifidobacterium spp. $+0.25 \%$ L. casei). One hundred and eighty laying hens (Lohmann strain), of 30 weeks old, were divided into 12 treatment groups, composed of five replicates, each consisting of three laying hens.
\end{abstract}

Results: The results showed that using $0.5 \%$ Bifidobacterium spp. $+0.25 \%$ L. casei in weeks 1 and 2 showed the lowest feed intake (FI) (112.11-112.19 g/day), the highest egg weight (60.28 g) in the $1^{\text {st }}$ week, the lowest feed conversion ratio (FCR) (2.21-2.23), and highest feed efficiency (44.75-45.25\%) for 3-4 weeks, and the highest hen-day production (86.66-86.90\%) for 3-4 weeks and the most profitable business analysis (IDR. 30,353).

Conclusion: Based on the results, it can be concluded that the addition of $0.5 \%$ Bifidobacterium spp. $+25 \%$ L. casei probiotics can be used as a substitute for AGP; it can reduce the FI and FCR, increasing egg weight, feed efficiency, and hen-day production, as well as illustrating the results of the most profitable business analysis.

Keywords: antibiotic growth promoters, business analysis, growth performance, hen-day production, probiotics.

\section{Introduction}

The use of antibiotics as growth promoters in poultry farms has been banned due to a myriad of reasons. In organic farms across Europe, the use of any drug, even for prevention or therapeutic purposes, is strictly monitored by the EC Council Regulation No. 1804/99 [1]. In Indonesia, it is overseen through the Minister of Agriculture Regulation No. 14 of 2017 concerning the Classification of Animal Medicine. The regulation is one of the government's strategic steps in controlling the threat of antimicrobial resistance [2]. The limitation of antibiotic use has triggered a lot of research in an effort to look for other

Copyright: Lokapirnasari, et al. Open Access. This article is distributed under the terms of the Creative Commons Attribution 4.0 International License (http://creativecommons.org/licenses/ by/4.0/), which permits unrestricted use, distribution, and reproduction in any medium, provided you give appropriate credit to the original author(s) and the source, provide a link to the Creative Commons license, and indicate if changes were made. The Creative Commons Public Domain Dedication waiver (http:// creativecommons.org/publicdomain/zero/1.0/) applies to the data made available in this article, unless otherwise stated. additives that could be used as an alternative for antibiotic growth promoters (AGPs). Probiotics is a feed additive that replaces the function of AGP in livestock includes probiotics.

Probiotics are live microbial cell preparations in the form of bacterial strains (generally lactic acid bacteria or Streptococcus) or yeast, which is given orally, alone or through a feed [3]. The use of probiotic supplementations containing beneficial bacteria, such as Lactobacillus spp. and Bifidobacterium spp. has a positive effect on the intestinal microbial population. Several researchers classify Bifidobacterium spp. and Lactobacillus casei as lactic acid bacteria categorized under probiotic microbial groups living in the digestive tract to improve its condition. The probiotic dose given through the poultry feed or drinking water is $0.1 \%-0.15 \%$ [4] or a $2 \%$ dose for more optimal results [5]. Giving probiotics to poultry could improve the feed conversion ratio (FCR), feed intake (FI), increase egg production, and stimulate growth rate as a result of hypocholesterolemic effects. The use of 
probiotics of different doses has been tested profusely, although an accurate dosage of administration has yet to be established [6].

Research on the use of probiotics as an alternative AGP is still very limited in obtaining high production results, impacting the economy of the livestock industry. This study aimed to determine the use of probiotics Bifidobacterium spp. and Lactobacillus casei as AGPs to improve growth performance and business analysis.

\section{Materials and Methods \\ Ethical approval}

An approval from the Institutional Ethical Committee (Faculty of Veterinary Medicine, Universitas Airlangga) was obtained before the experimental trial.

\section{Experimental design}

This research used a completely randomized factorial design pattern. The first factor was the time of administration at intervals of $1,2,3$, and 4 weeks, and the second was the use of probiotics: Control without probiotics, $0.1 \%$ AGP and $0.5 \%$ Bifidobacterium spp. $+0.25 \%$ L. casei. One hundred and eighty laying hens (Lohmann) of 30 weeks old were divided into $4 \times 3$ treatments, each group consisting of five replications made up of three. The dose of probiotics used in this study was based on the best doses that have been done in previous studies $[7,8]$.

\section{Rearing system}

Chicken placed in an individual battery cage $(20 \mathrm{~cm} \times 35 \mathrm{~cm} \times 35 \mathrm{~cm})$. Nutrient content of laying period was as follows: Dry matter: $91.97 \%$, ash: 9.28\%, crude protein: $20.71 \%$, extract ether: $6.36 \%$, crude fiber: $7.43 \%$; nitrogen-free extract: $48.18 \%$, and energy metabolism (EM: $2938.60 \mathrm{Mcal} / \mathrm{kg}$ ). The climatic conditions and lighting programs were operated and followed by the recommendations for the end of the experiment $\left( \pm 28-32^{\circ} \mathrm{C}\right.$; length lighting; $16 \mathrm{~h} /$ day; humidity; 55-65\%).

To administer AGP, $0.1 \%$ AGP was mixed into the feed and evenly stirred. To administer the probiotics, $0.5 \%$ Bifidobacterium spp. $+0.25 \%$ L. casei (each concentration of $1.2 \times 10^{8}$ colony forming units $[\mathrm{CFU}] / \mathrm{ml}$ ) was mixed with $7.5 \mathrm{ml} / \mathrm{L}$ of water (free of chlorine and other disinfectants). The probiotic solution was evenly sprayed on to a $1 \mathrm{~kg}$ feed ration, which was then dried for feeding. Probiotic solutions were freshly sprayed on the rations every day. Provision of feed rations in chickens was carried out every morning at $08.00 \mathrm{am}$ and every noon at $1.00 \mathrm{pm}$. Drinking places were cleaned every day, while cage disinfection was conducted twice a month.

Diet composition was appropriate for the growing period of the hens and met the Standard National Indonesia requirements. Unconsumed feed was weighed and discarded weekly, and feed consumption data were carried out every week during the 4 weeks of treatment.
The analysis of growth performance was calculated using:

Feed intake (g) = Amount of feed given (g)-Amount of unconsumed feed;

$\mathrm{FCR}=$ Feed intake/Egg production;

Feed efficiency $=($ Egg production $/$ Feed intake $) \times 100$; Hen-day production $=$ Number of eggs per day $\times 100$.

The business analysis consisted of calculating the variable costs, receipts, and benefits of the control treatment (b0), use of $0.1 \%$ AGP (b1), and $0.5 \%$ Bifidobacterium spp. $+0.25 \%$ L. casei (b2) for 4 weeks of treatment.

The following formula was designed:

Total revenue $=$ Price per unit $\times$ Total production;

Total cost $=$ Total fixed cost + Total variable cost; Profit $=$ Total revenue - Total cost.

\section{Statistical analysis}

Data were analyzed statistically using a univariate general linear model statistics to determine whether there were any interaction and significant differences between treatments. If the results were significantly different, then it was processed with the Duncan's Multiple Distance Test. Data were then analyzed using the SPSS (IBM Corporation, USA) for Windows 22.0 program.

\section{Results}

\section{FI}

In the first factor, the difference in the length of time the additive feed is given shows a significant difference $(p<0.05)$ to the FI. The lowest FI $s$ are shown in administration for 1 week and 2 weeks, while the higher FIs are shown in administration for 3 and 4 weeks. In the second factor, giving a variety of feed additive showed a significant difference $(p<0.05)$ between the treatment of the FI. The lowest FI was found with $0.5 \%$ Bifidobacterium spp. $+0.25 \%$ L. casei, followed by AGP. The highest FI was found in the control treatment. The results of this study indicate that there is an interaction $(p<0.05)$ between the differences in the length of time given feed additive and the type of feed additive to FI in laying hens. The measurements of an average of FI in the treatment are listed in Table-1.

\section{Egg weight}

There was a correlation between the length of time given by the factor feed additive both the use of AGP or $0.5 \%$ Bifidobacterium spp. $+0.25 \%$ L. casei and the weight of the eggs in laying hens. The highest egg weight is shown in administration for 1 week and the highest egg weight was found in $0.5 \%$ Bifidobacterium spp. $+0.25 \%$ L. casei, which was not different from the egg weight at $0.1 \%$ AGP. The lowest egg weight was in control without AGP and probiotics, and there was no significant difference found when compared to the administration for the second and fourth. The $0.5 \%$ Bifidobacterium spp. $+0.25 \%$ L. casei in the $2^{\text {nd }}, 3^{\text {rd }}$, and $4^{\text {th }}$ weeks 
showed no difference compared to the use of $0.1 \%$ AGP in the $2^{\text {nd }}$ and $3^{\text {rd }}$ weeks. This shows that giving $0.5 \%$ Bifidobacterium spp. $+0.25 \%$ L. casei and $0.1 \%$ AGP provide relatively similar results. The measurements of egg weight during the 4 weeks of AGP and probiotic administration are listed in Table-2.

\section{FCR and feed efficiency}

In the first factor, the difference in the length of time the additive feed was given shows a significant difference $(p<0.05)$ to the FCR and feed efficiency. The lowest FCR was shown in administration for 1 week, 3 and 4 weeks, while the higher FCR was shown in administration for 2 weeks. In the second factor, giving a variety of feed additive showed a significant difference $(p<0.05)$ between the treatment of the FCR. The lowest FCR was found with $0.5 \%$ Bifidobacterium spp. $+0.25 \%$ L. casei followed by AGP. The highest FCR was found in the control treatment. There was an interaction $(p<0.05)$ between the length of time given feed additive and the type of feed additive to FCR in laying hens. Data from the research on FCR are listed in Table-3. The best conversion ratio $(2.21-2.45)$ was produced at $0.5 \%$ Bifidobacterium spp. $+0.25 \%$ L. casei for $1-4$ weeks administration. The results of the average FCR are listed in Table-3.

There was an interaction between the length of time given by the feed additive factor and the use of AGP or $0.5 \%$ Bifidobacterium spp. $+0.25 \%$ L. case $i$ in feed efficiency of laying hens. The highest feed efficiency results were indicated by giving $0.5 \%$ Bifidobacterium spp. $+0.25 \%$ L. casei for 3-4 weeks. The lowest feed efficiency was found in the control where AGP and probiotics were not given, both in the $1^{\text {st }}$ week and the $4^{\text {th }}$ week of treatment. The results of the average feed efficiency are listed in Table-4.

\section{Hen-day production}

In the first factor, the difference in the length of time the additive feed was given shows a significant difference $(p<0.05)$ to the hen-day production. The highest HDP were shown in administration for 3 weeks and 4 weeks, while the lower HDP were

Table-1: Average of feed intake in the treatment (gram/hen/day).

\begin{tabular}{|c|c|c|c|c|}
\hline \multirow[t]{2}{*}{ Week factor } & \multicolumn{3}{|c|}{ Feed additive factor } & \multirow{2}{*}{$\begin{array}{c}\text { Average } \\
\text { feed intake }\end{array}$} \\
\hline & Control (bo) & $0.1 \%$ AGP (b1) & $\begin{array}{c}0.5 \% \text { Bifidobacterium spp. } \\
+0.25 \% \text { L. casei (b2) }\end{array}$ & \\
\hline $1(\mathrm{a} 0)$ & $115.14 \pm 0.87$ & $113.04 \pm 0.73$ & $112.11 \pm 0.78$ & $113.43^{a} \pm 1.55$ \\
\hline $2(a 1)$ & $115.32 \pm 0.50$ & $113.18 \pm 0.40$ & $112.19 \pm 0.58$ & $113.56^{a} \pm 1.60$ \\
\hline $3(a 2)$ & $116.34 \pm 0.76$ & $114.47 \pm 1.08$ & $113.42 \pm 1.35$ & $114.74^{b} \pm 1.48$ \\
\hline $4(a 3)$ & $116.35 \pm 0.42$ & $114.62 \pm 0.71$ & $113.60 \pm 0.75$ & $114.86^{b} \pm 1.39$ \\
\hline Average feed intake & $115.79^{c} \pm 0.65$ & $113.83^{b} \pm 0.83$ & $112.83^{a} \pm 0.79$ & \\
\hline \multirow[t]{8}{*}{ Interactions $a \times b$} & $\mathrm{a} 0 \times \mathrm{b} 0$ & $\mathrm{a} 0 \times \mathrm{b} 1$ & $\mathrm{a} 0 \times \mathrm{b} 2$ & \\
\hline & $115.14^{c} \pm 0.87$ & $113.04^{b} \pm 0.73$ & $112.11^{\mathrm{a}} \pm 0.78$ & \\
\hline & $\mathrm{a} 1 \times \mathrm{b} 0$ & $\mathrm{a} 1 \times \mathrm{b} 1$ & $a 1 \times b 2$ & \\
\hline & $115.14^{c} \pm 0.51$ & $113.04^{b} \pm 0.41$ & $112.11^{\mathrm{a}} \pm 0.59$ & \\
\hline & $\mathrm{a} 2 \times \mathrm{b} 0$ & $\mathrm{a} 2 \times \mathrm{b} 1$ & $\mathrm{a} 2 \times \mathrm{b} 2$ & \\
\hline & $116.34^{\mathrm{b}} \pm 0.76$ & $114.47^{a} \pm 1.09$ & $113.42^{\mathrm{a}} \pm 1.36$ & \\
\hline & $a 3 \times b 0$ & $\mathrm{a} 3 \times \mathrm{b} 1$ & $a 3 \times b 2$ & \\
\hline & $116.35^{`} \pm 0.42$ & $114.62^{b} \pm 0.71$ & $113.60^{\mathrm{a}} \pm 0.75$ & \\
\hline
\end{tabular}

$a, b, c$ Different superscripts in the same raw show significant difference $(p<0.05)$. AGP=Antibiotic growth promoters

Table-2: Average of egg weight in the treatment (gram/egg).

\begin{tabular}{|c|c|c|c|c|}
\hline \multirow[t]{2}{*}{ Week factor } & \multicolumn{3}{|c|}{ Feed additive factor } & \multirow{2}{*}{$\begin{array}{l}\text { Average } \\
\text { egg weight }\end{array}$} \\
\hline & Control (b0) & $0.1 \%$ AGP (b1) & $\begin{array}{c}0.5 \% \text { Bifidobacterium spp. } \\
+0.25 \% \text { L. casei (b2) }\end{array}$ & \\
\hline $\begin{array}{l}1(\mathrm{a} 0) \\
2(\mathrm{a} 1) \\
3(\mathrm{a} 2) \\
4 \text { (a3) } \\
\text { Average egg weight } \\
\text { Interactions } a \times b\end{array}$ & $\begin{array}{c}60.00 \pm 0.81 \\
58.71 \pm 0.48 \\
58.42 \pm 0.78 \\
58.71 \pm 0.48 \\
58.96^{\mathrm{a}} \pm 0.71 \\
a 0 \times \mathrm{b} 0 \\
60.00^{\mathrm{a}} \pm 0.82 \\
\mathrm{a} 1 \times \mathrm{b} 0 \\
60.00^{\mathrm{a}} \pm 0.49 \\
\mathrm{a}^{2} \times \mathrm{b} 0 \\
58.42^{\mathrm{a}} \pm 0.79 \\
a 3 \times \mathrm{b} 0 \\
58.71^{\mathrm{a}} \pm 0.49\end{array}$ & $\begin{array}{c}59.71 \pm 0.48 \\
59.28 \pm 0.48 \\
59.00 \pm 0.81 \\
60.00 \pm 0.81 \\
59.50^{\mathrm{b}} \pm 0.44 \\
a 0 \times \mathrm{b} 1 \\
59.71^{\mathrm{a}} \pm 0.49 \\
a 1 \times \mathrm{b} 1 \\
59.71^{\mathrm{a}} \pm 0.49 \\
a 2 \times \mathrm{b} 1 \\
59.00^{\mathrm{a}} \pm 0.82 \\
a 3 \times \mathrm{b} 1 \\
60.00^{\mathrm{b}} \pm 0.82\end{array}$ & $\begin{array}{c}60.28 \pm 0.75 \\
58.57 \pm 0.53 \\
58.57 \pm 0.78 \\
59.14 \pm 0.69 \\
59.14^{\mathrm{ab}} \pm 0.81 \\
a 0 \times \mathrm{b} 2 \\
60.28^{\mathrm{a}} \pm 0.76 \\
a 1 \times \mathrm{b} 2 \\
60.28^{\mathrm{a}} \pm 0.53 \\
a 2 \times \mathrm{b} 2 \\
58.57^{\mathrm{a}} \pm 0.79 \\
a 3 \times \mathrm{b} 2 \times \mathrm{b} 2 \\
59.14^{\mathrm{a}} \pm 0.69\end{array}$ & $\begin{array}{l}60.00^{a} \pm 0.29 \\
58.85^{c} \pm 0.38 \\
58.66^{c} \pm 0.30 \\
59.28^{b} \pm 0.66\end{array}$ \\
\hline
\end{tabular}

$a, b, c$ Different superscripts in the same raw show significant difference $(p<0.05)$. AGP=Antibiotic growth promoters, L. casei=Lactobacillus case $i$ 
Table-3: Average of FCR in the treatment.

\begin{tabular}{|c|c|c|c|c|}
\hline \multirow[t]{2}{*}{ Week factor } & \multicolumn{3}{|c|}{ Feed additive factor } & \multirow{2}{*}{$\begin{array}{l}\text { Average } \\
\text { FCR }\end{array}$} \\
\hline & Control (b0) & $0.1 \%$ AGP (b1) & $\begin{array}{c}0.5 \% \text { Bifidobacterium spp. } \\
+0.25 \% \text { L. casei (b2) }\end{array}$ & \\
\hline $1(\mathrm{a} 0)$ & $2.54 \pm 0.04$ & $2.54 \pm 0.04$ & $2.45 \pm 0.08$ & $2.53^{c} \pm 0.05$ \\
\hline $2(a 1)$ & $2.61 \pm 0.02$ & $2.46 \pm 0.06$ & $2.32 \pm 0.04$ & $2.46^{b} \pm 0.15$ \\
\hline $3(\mathrm{a} 2)$ & $2.63 \pm 0.02$ & $2.40 \pm 0.03$ & $2.23 \pm 0.03$ & $2.41^{\mathrm{a}} \pm 0.20$ \\
\hline $4(\mathrm{a} 3)$ & $2.62 \pm 0.04$ & $2.41 \pm 0.06$ & $2.21 \pm 0.05$ & $2.41^{\mathrm{a}} \pm 0.21$ \\
\hline Average FCR & $2.61^{\mathrm{c}} \pm 0.04$ & $2.45^{b} \pm 0.06$ & $2.30^{\mathrm{a}} \pm 0.11$ & \\
\hline \multirow{8}{*}{ Interactions $\mathrm{a} \times \mathrm{b}$} & $\mathrm{a} 0 \times \mathrm{b} 0$ & $\mathrm{a} 0 \times \mathrm{b} 1$ & $\mathrm{a} 0 \times \mathrm{b} 2$ & \\
\hline & $2.62^{c} \pm 0.04$ & $2.54^{b} \pm 0.04$ & $2.45^{\mathrm{a}} \pm 0.08$ & \\
\hline & $\mathrm{a} 1 \times \mathrm{b} 0$ & $\mathrm{a} 1 \times \mathrm{b} 1$ & $\mathrm{a} 1 \times \mathrm{b} 2$ & \\
\hline & $2.62^{c} \pm 0.03$ & $2.54^{b} \pm 0.07$ & $2.45^{a} \pm 0.05$ & \\
\hline & $\mathrm{a} 2 \times \mathrm{b} 0$ & $\mathrm{a} 2 \times \mathrm{b} 1$ & $\mathrm{a} 2 \times \mathrm{b} 2$ & \\
\hline & $2.60^{\circ} \pm 0.02$ & $2.40^{\mathrm{b}} \pm 0.04$ & $2.23^{\mathrm{a}} \pm 0.03$ & \\
\hline & $\mathrm{a} 3 \times \mathrm{b} 0$ & $\mathrm{a} 3 \times \mathrm{b} 1$ & $\mathrm{a} 3 \times \mathrm{b} 2$ & \\
\hline & $2.61^{c} \pm 0.05$ & $2.41^{b} \pm 0.06$ & $2.21^{\mathrm{a}} \pm 0.06$ & \\
\hline
\end{tabular}

$a, b, c$ Different superscripts in the same raw show significant difference $(p<0.05)$. FCR $=$ Feed conversion ratio,

L. casei=Lactobacillus casei

Table-4: Average of feed efficiency in the treatment.

\begin{tabular}{|c|c|c|c|c|}
\hline \multirow[t]{2}{*}{ Week factor } & \multicolumn{3}{|c|}{ Feed additive factor } & \multirow{2}{*}{$\begin{array}{l}\text { Average feed } \\
\text { efficiency }\end{array}$} \\
\hline & Control (b0) & $0.1 \%$ AGP (b1) & $\begin{array}{l}0.5 \% \text { Bifidobacterium spp. } \\
+0.25 \% \text { L. casei (b2) }\end{array}$ & \\
\hline $\begin{array}{l}1(\mathrm{a} 0) \\
2(\mathrm{a} 1) \\
3(\mathrm{a} 2) \\
4(\mathrm{a} 3) \\
\text { Average feed efficiency } \\
\text { Interactions } \mathrm{a} \times \mathrm{b}\end{array}$ & $\begin{array}{c}38.08 \pm 0.60 \\
38.05 \pm 0.37 \\
38.37 \pm 0.32 \\
38.32 \pm 0.69 \\
38.21^{\mathrm{a}} \pm 0.16 \\
\mathrm{a} 0 \times \mathrm{b} 0 \\
38.08^{\mathrm{a}} \pm 0.61 \\
\mathrm{a} 1 \times \mathrm{b} 0 \\
38.08^{\mathrm{a}} \pm 0.38 \\
\mathrm{a} 2 \times \mathrm{b} 0 \\
38.37^{\mathrm{a}} \pm 0.32 \\
\mathrm{a} 3 \times \mathrm{b} 0 \\
38.32^{\mathrm{a}} \pm 0.70\end{array}$ & $\begin{array}{c}39.36 \pm 0.65 \\
40.66 \pm 1.15 \\
41.60 \pm 0.70 \\
41.50 \pm 1.07 \\
40.78^{\mathrm{b}} \pm 1.04 \\
\mathrm{a} 0 \times \mathrm{b} 1 \\
39.36^{\mathrm{b}} \pm 0.66 \\
\mathrm{a} 1 \times \mathrm{b} 1 \\
39.36^{\mathrm{b}} \pm 1.15 \\
\mathrm{a} 2 \times \mathrm{b} 1 \\
41.60^{\mathrm{b}} \pm 0.71 \\
\mathrm{a} 3 \times \mathrm{b} 1 \\
41.50^{\mathrm{b}} \pm 1.08\end{array}$ & $\begin{array}{c}40.85 \pm 1.38 \\
43.12 \pm 0.84 \\
44.75 \pm 0.64 \\
45.25 \pm 1.19 \\
43.49^{\circ} \pm 1.98 \\
a 0 \times b 2 \\
40.85^{\circ} \pm 1.39 \\
a 1 \times b 2 \\
40.85^{\circ} \pm 0.84 \\
a 2 \times b 2 \\
44.75^{\circ} \pm 0.65 \\
a 3 \times b 2 \\
45.25^{\circ} \pm 1.19\end{array}$ & $\begin{array}{l}39.43^{a} \pm 1.39 \\
40.61^{b} \pm 2.54 \\
41.57^{c} \pm 3.19 \\
41.69^{c} \pm 3.47\end{array}$ \\
\hline
\end{tabular}

$a, b, c$ Different superscripts in the same raw show significant difference $(p<0.05)$. AGP=Antibiotic growth promoters,

L. casei=Lactobacillus casei

shown in administration for 2 and 1 weeks, respectively. In the second factor, giving a variety of feed additive showed a significant difference $(\mathrm{p}<0.05)$ between the treatment of the HDP. The highest HDP was found with $0.5 \%$ Bifidobacterium spp. $+0.25 \%$ L. casei followed by AGP. The lowest HDP was found in the control treatment. A correlation was identified between the length of time given by the factor feed additive with the use of either AGP or $0.5 \%$ Bifidobacterium spp. $+0.25 \%$ L. casei to hen-day production in laying hens. The highest hen-day production was shown by giving $0.5 \%$ Bifidobacterium spp. $+0.25 \%$ L. casei for 3-4 weeks followed by 2 and 1 week. Data from the research on HDP care shown in Table-5.

\section{Business analysis}

The business analysis consists of calculating variable costs, revenues, and profits. The results of the calculation of the average variable costs, acceptance and control advantages, and the use of AGP and probiotics are listed in Table- 6 .

\section{Discussion}

FI

FI is the amount of ration consumed by chickens over $24 \mathrm{~h}$, calculated using the difference between the feed given and the feed left over. Based on the results in Table-1, there were significant differences $(p<0.05)$ among treatments. The lowest FI was found in the use of a combination of $0.5 \%$ Bifidobacterium spp. + $0.25 \%$ L. casei for $1-4$ weeks. The highest FI results were found in control without the use of feed additives in the 1,2 , and $4^{\text {th }}$ weeks. A high FI is a result of limited absorption of nutrients in the small intestine, therefore, that the feed ration consumed by chickens is greater. A previous study found that a good FI is shown by giving $0.5 \%$ Bifidobacterium spp. $+0.25 \%$ L. casei to layer chickens, showing similar results to the current study [9] using probiotics containing Bifidobacterium thermophilum, Lactobacilli, and Enterococcus faecium. Administering probiotics to chickens can increase jejunal villus height and reduce the villus-crypt depth. The use of Lactobacillus 
Table-5: Average of hen-day production in the treatment.

\begin{tabular}{|c|c|c|c|c|}
\hline \multirow[t]{2}{*}{ Week factor } & \multicolumn{3}{|r|}{ Feed additive factor } & \multirow{2}{*}{$\begin{array}{c}\text { Average } \\
\text { HDP }\end{array}$} \\
\hline & Control (bo) & $0.1 \%$ AGP (b1) & $0.5 \%$ Bifidobacterium spp. $+0.25 \%$ L. casei (b2) & \\
\hline $1(\mathrm{a} 0)$ & $73.09 \pm 1.49$ & $74.52 \pm 1.26$ & $75.95 \pm 1.31$ & $74.52^{\mathrm{a}} \pm 1.43$ \\
\hline $2(\mathrm{a} 1)$ & $74.76 \pm 1.50$ & $77.62 \pm 1.62$ & $82.61 \pm 1.88$ & $78.33^{\mathrm{b}} \pm 3.97$ \\
\hline $3(\mathrm{a} 2)$ & $76.43 \pm 1.50$ & $80.71 \pm 0.89$ & $86.66 \pm 1.66$ & $81.27^{c} \pm 5.14$ \\
\hline $4(\mathrm{a} 3)$ & $75.95 \pm 0.89$ & $79.28 \pm 1.62$ & $86.90 \pm 1.49$ & $80.71^{c} \pm 5.61$ \\
\hline Average HDP & $75.06^{a} \pm 1.49$ & $78.03^{b} \pm 2.66$ & $83.03^{c} \pm 5.11$ & \\
\hline \multirow[t]{8}{*}{ Interactions $a \times b$} & $\mathrm{a} 0 \times \mathrm{b} 0$ & $\mathrm{a} 0 \times \mathrm{b} 1$ & $\mathrm{a} 0 \times \mathrm{b} 2$ & \\
\hline & $73.09^{\mathrm{a}} \pm 1.50$ & $74.52^{\mathrm{ab}} \pm 1.26$ & $75.95^{\mathrm{b}} \pm 1.31$ & \\
\hline & $\mathrm{a} 1 \times \mathrm{b} 0$ & $\mathrm{a} 1 \times \mathrm{b} 1$ & $\mathrm{a} 1 \times \mathrm{b} 2$ & \\
\hline & $73.09^{\mathrm{a}} \pm 1.50$ & $74.52^{\mathrm{ab}} \pm 1.62$ & $75.95^{\mathrm{b}} \pm 1.89$ & \\
\hline & $\mathrm{a} 2 \times \mathrm{b} 0$ & $\mathrm{a} 2 \times \mathrm{b} 1$ & $\mathrm{a} 2 \times \mathrm{b} 2$ & \\
\hline & $76.43^{\mathrm{a}} \pm 1.50$ & $80.71^{b} \pm 0.89$ & $86.66^{c} \pm 1.67$ & \\
\hline & $\mathrm{a} 3 \times \mathrm{b} 0$ & $\mathrm{a} 3 \times \mathrm{b} 1$ & $\mathrm{a} 3 \times \mathrm{b} 2$ & \\
\hline & $75.95^{\mathrm{a}} \pm 0.89$ & $79.28^{\mathrm{b}} \pm 1.63$ & $86.90^{c} \pm 1.50$ & \\
\hline
\end{tabular}

$a, b, c$ Different superscripts in the same raw show significant difference $(p<0.05)$. AGP=Antibiotic growth promoters, L. case $i=$ Lactobacillus case $i$

Table-6: The average variable costs, revenue, and profit of control, and the use of AGP and probiotics.

\begin{tabular}{|c|c|c|c|}
\hline \multirow[t]{2}{*}{ Treatment } & Variable costs & Revenue & Profit \\
\hline & (IDR/day) & (IDR/day) & (IDR/day) \\
\hline Control (b0) & $38.364 .74^{\complement} \pm 198.01$ & $61.082 .50^{\complement} \pm 1502.84$ & $22.717 .79^{c} \pm 1694.16$ \\
\hline $0.1 \%$ AGP (b1) & $37.719 .01^{b} \pm 241.70$ & $64.010 .80^{b} \pm 1272.51$ & $26.291 .80^{\mathrm{b}} \pm 1361.36$ \\
\hline $\begin{array}{l}0.5 \% \text { Bifidobacterium spp. + } \\
0.25 \% \text { L. casei (b2) }\end{array}$ & $37.372 .17^{a} \pm 213.46$ & $67.725 .68^{a} \pm 2039.11$ & $30.353 .52^{\mathrm{a}} \pm 2012.40$ \\
\hline
\end{tabular}

$a, b, c$ Different superscripts in the same raw show significant difference $(p<0.05)$. AGP $=$ Antibiotic growth promoter

acidophilus has a positive role in poultry intestinal mucosa because it strengthens the barrier effect. However, the positive effects are dependent on the adhesion and replication on the intestinal wall [10] hence why the use of probiotics containing $B$. subtilis, B. subtilis C-3102 [11-13], L. acidophilus and a mixture of Lactobacillus spp., B. cereus in broiler chickens, can increase the concentration of volatile fatty acids in the ileum and cecum, as well as reduce the $\mathrm{pH}$ value. Decreased $\mathrm{pH}$ in the digestive tract is associated with a decline in the number of $E$. coli forms and an increase in bacteria which is beneficial for the intestines [14]. The decrease in the population of $E$. coli in the intestine is associated with an increase in the number of Lactobacillus spp. [10]. It supports the hypothesis that Lactobacilli could compete with E. coli for intestinal colonization. Watkins observed that a competitive exclusion against pathogenic $E$. coli strains occurred in gnotobiotic chicks that were fed $L$. acidophilus. Probiotics contain antagonistic abilities toward several pathogenic bacteria, such as E. coli, Salmonella spp., and Shigella spp. [15].

Administering combination cultures of Lactobacillus and Bacillus spp. in laying hens showed the results of increased feed consumption and drinking water [16]. Viable Lactobacillus at $1100 \mathrm{mg} / \mathrm{kg}$ $\left(4.4 \times 10^{7} \mathrm{CFU} / \mathrm{kg}\right)$ dramatically increased egg size, daily feed consumption, calcium retentions, and nitrogen [17]. Some of the results, however, did not show an increase in feed consumption [18], egg production, and egg weight [19]. There seemed to be no effect on
FI, egg production, or egg mass of hens throughout the 48 weeks [20].

Feed intake and the energy balance in poultry, influenced by genetic regulation [21]. Growth and fat deposition are related to the level of FI and feed efficiency, which can be affected by several genes; those that are significantly related to the FI are LCORL (ligand-dependent nuclear receptor corepressor-like) and NCAPG (non-SMC condensin I complex, subunit $G$ ) genes [22]. Egg production and egg weight are also affected by the chromosome position [23]. The increase in FI in the administration of probiotics is due to an increase in digestion, absorption, and availability of nutrition, positively effecting intestine activity, and increasing digestive enzymes [24].

\section{Egg weight}

There is an interaction between the length of time given by the feed additive with either the use of AGP or $0.5 \%$ Bifidobacterium spp. $+0.25 \%$ L. casei on egg weight in laying hens. Data from research results on Egg weight are presented in Table-5.

The addition of probiotics did not have a significant effect on egg production and mass, but it did affect egg weight [25]. The same result was reported that supplementation of Lactobacillus cultures did not influence the egg production of hens throughout the experimental period and no significant difference in egg weight in hens fed with L. acidophilus [20]. Other research could also not identify a significant improvement in egg production of hens supplemented with PrimaLac containing Lactobacillus 
species [26]. The highest egg weight was found in the recent study of $0.5 \%$ Bifidobacterium spp. $+0.25 \%$ L. casei, while the lowest egg weight was in control without the use of AGP or probiotics. The mechanism of given probiotic to laying hens in the present study could be due to a decrease of pathogenic bacteria proliferation resulting from a change in the environment of the gastrointestinal tract and enhanced nutrient utilization, and it could be due to increased enzymatic activity in the gut resulting in improving nutrient utilization [27]. Giving the probiotics could improve the structure of the intestinal mucosa, increased villus length of the intestinal mucosa implies that there would be an increased surface area for nutrient absorption [28].

\section{FCR and feed efficiency}

The FCR is the result of a comparison between the FI $(\mathrm{g})$ and egg production $(\mathrm{g})$. The results showed that there were significant differences $(p<0.05)$ between treatments, the lowest FCR being found in the treatment of $0.5 \%$ Bifidobacterium spp. $+0.25 \%$ L. casei was used for 1-4 weeks. The highest feed conversion results were found in control without the use of AGP or probiotics in week 1, 2, 3, and week 4 . The giving of $0.5 \%$ Bifidobacterium spp. $+0.25 \%$ L. casei for 1-4 weeks showed FCR results that were significantly different from the administration of $0.1 \%$ AGP for weeks 1, 2, 3, and 4. High FCR results were found in controls without the giving of AGP and probiotics. High FCR results showed lower feed efficiency. The low FCR is caused by giving probiotics can reduce feed consumption, but the egg production produced is the highest. The decrease in FCR indicates an increase in feed efficiency ratio. Feed efficiency can be used to evaluate the efficacy of nutrient and energy metabolic processes. Increased feed efficiency has a positive impact because it can reduce production costs for producers. FCR is the main index to find out and assess feed efficiency in livestock because it affects the increase in growth performance. Feed efficiency is influenced by several factors, not only by physiological states and genetic hosts but also by the intestinal microbiota. Microbiota in the intestinal tract can affect nutrient digestion and energy absorption in the host. Lactobacillus is one of the most dominant microbiotas found in the duodenum in chickens, resulting in better feed efficiency [29]. This improvement in feed efficiency and reduction in FCR by additional probiotic could be related to its promoting effects on metabolism of digestion processes and utilization of nutrients [27]. The other study supplemented probiotic with $0.1 \%$ and $0.2 \%$ in laying hens (age 54 weeks) for 3 months reported an increase in egg production and decreases in FCR and FI [30]. The mechanism explained that the increased egg production by probiotic might be due to the elongated shape of small and large intestine as well as their suppressing effects on pathogen bacteria and stimulating effects on the growth and activity of beneficial bacteria probiotic in the intestines which increase absorption of nutrient [31].

The administration of Lactobacillus and Bifidobacterium in this study is consistent with Yan that Lactobacillus is strongly associated with feed efficiency in the host. Lactobacillus is a beneficial bacteria that are commensal, which is beneficial to humans and animals. It can be concluded that Lactobacillus enriched generally can improve the digestive tract and thus protect the intestine from pathogens and promote efficient nutrition and energy extraction in the host. Changes in the composition of the microbiota in the intestine will affect host metabolism [32,33].

\section{Hen-day production}

There is an established relationship between the length of time given by the factor feed additive and either the use of AGP or $0.5 \%$ Bifidobacterium spp. + $0.25 \% \mathrm{~L}$. casei to hen-day production in laying hens. Data from the research on hen-day production are shown in Table-5.

Hen-day production is a comparison of egg production and the number of chickens multiplied by 100 . The results found significant differences $(p<0.05)$ between treatments. The highest hen-day production is found in the treatment of a $2 \mathrm{~b} 2$ and $\mathrm{a} 3 \mathrm{~b} 2$, where $0.5 \%$ Bifidobacterium spp. $+0.25 \%$ L. casei is used in the $3^{\text {rd }}$ and $4^{\text {th }}$ weeks of HDP of $86.66 \%$ and $86.90 \%$. The lowest hen-day production is found in the control for 1-4 weeks. The use of AGP shows lower hen-day production values of $14.24 \%$ compared to probiotic use.

The administration of probiotics containing Bifidobacterium and L. casei is in accordance with studies that report the use of liquid probiotic mixed culture probiotics containing two types of microorganisms, Lactobacillus and Bacillus species. These species showed the highest yield day production and egg weight in layers [16], as well as in laying hens given a mixed culture of $L$. acidophilus, $L$. casei, and L. acidophilus [34]. Those given probiotics showed significant improvement in egg production and that layers fed with probiotics contained Bifidobacterium bifidum, Lactobacillus plantarum, L. acidophilus, Lactobacillus delbrueckii subsp. bulgaricus, Lactobacillus rhamnosus, Streptococcus salivarius subsp. thermophilus, Aspergillus oryzae, E. faecium, and Candida pintolopesii showed greater egg production than the group fed with basal diet [30].

Control group shows the lowest HDP value as a result of the absorption of nutrients that are limited compared to the treatment with the use of AGP or probiotic feed additives. The AGP treatment showed higher egg production compared to control because the addition of AGP in the ration helped reduce the number of intestinal microflora and suppressed the growth of pathogenic bacteria in the digestive tract. However, the disadvantage of using AGP includes a residue from the antibiotics being detected in livestock products 
such as meat, eggs, and milk, which is dangerous for consumers. The combination of $0.5 \%$ Bifidobacterium spp. $+0.25 \%$ L. casei showed the highest egg production results. This is because probiotics can produce an acidic atmosphere in the digestive tract, therefore suppressing the growth of pathogenic bacteria. The condition of a good digestive tract can help improve the metabolic process and absorption of nutrients needed by the body. Provision of probiotics $L$. casei and $L$. rhamnosum can increase feed efficiency and egg production while reducing production costs [35]. The use of probiotics can improve egg production, eggshell weight, eggshell thickness, and reduce cholesterol levels in the egg yolk [36].

\section{Business analysis}

Business analysis consists of calculating variable costs, receipts, and profits. The results of calculation over 4 weeks are listed in Table-6, highlighting significant differences $(p<0.05)$ between treatments $b 0$, $\mathrm{b} 1$, and b2.

\section{Variable costs}

Variable costs are the number of marginal costs for all units produced. They are calculated by multiplying the cost of feed and the additives (AGP and Probiotics) by the number of livestock units. Table- 6 shows that there are significant differences $(p<0.05)$ between treatments $b 0, b 1$, and $b 2$. The highest variable cost in treatment b0 is IDR. 38,364.74, because the average FI for 4 weeks of treatment without AGP or probiotics is equal to $115.79 \mathrm{~g} / \mathrm{head} / \mathrm{day}$. In the treatment with $0.1 \%$ AGP (b1), a lower variable cost was produced IDR. 37,719.01, compared to b0. b1 had an average FI for 4 weeks treatment of $113.83 \mathrm{~g} / \mathrm{head} /$ day. The lowest variable cost in the treatment of $b 2$ is IDR. 37,372.17, with an average FI for 4 weeks treatment of $112.83 \mathrm{~g} / \mathrm{head} /$ day.

\section{Revenue}

Revenue is the selling price per unit of production multiplied by the number of products sold. It is determined by egg production, the higher it is, the higher the acceptance that will be received.

Table-6 shows that a significant difference $(p<0.05)$ was found among treatments. The treatment of b0, with the provision of basal feed without probiotics or AGP, had the lowest egg sales revenue at IDR 61,082.50, with an HDP of 75.06\%. Treatment of b1 shows lower results than P2 at IDR. 64,010.80, with an HDP of $78.03 \%$. The highest treatment was b2, with egg sales totaling IDR. $67,725.68$, with an HDP of $83.03 \%$.

\section{Profit}

Profits are obtained through total income minus production costs. To meet the conditions of profit, the income has to be greater than the cost of production. Based on Table- 6 showed a significant difference $(p<0.05)$ among treatments. Treatment b2 shows the largest profit of totaling IDR. 30,353.52, a result of the lowest variable costs and the highest revenues.
Treatment b1 has a profit of Rp. 26,291.80, while b0 is the treatment with the lowest profit at IDR. $22,717.79$, having the highest variable costs and the lowest receipts. The advantages of probiotic use (a combination of $0.5 \%$ Bifidobacterium spp. $+25 \%$ L. casei) include improving feed efficiency to reduce the overall cost, as well as increasing egg production. The lower costs of feed and higher production of eggs determine increased profits for farmers.

\section{Conclusion}

Based on the results, it can be concluded that the addition of $0.5 \%$ Bifidobacterium spp. $+25 \%$ L. casei probiotics can be used as an alternative substitute for AGP. The use of probiotics can reduce the FI and FCR, therefore increasing egg weight, feed efficiency, and hen-day production, as well as illustrating the results of the most profitable business analysis.

\section{Authors' Contributions}

WPL designed, interpreted, and analyzed data in the research and drafted manuscript; $\mathrm{SH}, \mathrm{NH}, \mathrm{SS}$, and $\mathrm{ABY}$ interpreted data; TBP, RN, KH, HCPW, and NFNR conducted the field experimental work and participated in data collection; and AA who analyzed and interpreted the data. All authors read and approved the final manuscript.

\section{Acknowledgments}

The author would like to thank the Rector of Airlangga University, Chairman of the Research and Innovation Institute, Chairman of Halal Research Center and the Dean of Faculty of Veterinary Medicine Universitas Airlangga, Indonesia, for providing funding to conduct this research (contract No: 886/UN3/2018).

\section{Competing Interests}

The authors declare that they have no competing interests.

\section{Publisher's Note}

Veterinary World remains neutral with regard to jurisdictional claims in published institutional affiliation.

\section{References}

1. EC Council Regulation. (1999) EC Council Regulation No. 1804/99 of July 1999 Supplementing Regulation (EEC) No. 2092/91 on Organic Production of Agricultural Products. Official Journal L. 222128.

2. Permentan. (2017) Regulation of the Minister of Agriculture Republic Indonesia Nomor14/PERMENTAN/ PK.350/5/2017 about Classification of Animal Medicine. Ministry of Agriculture, Jakarta.

3. Kochewad, S.A., Chahande, J.M., Kanduri, A.B., Deshmukh, D.S., Ali, S.A. and Patil, V.M. (2009) Effect of probiotic supplementation on growth parameters of Osmanabadi kids. Vet. World, 2(1): 29.

4. Rowghani, E., Arab, M. and Akbarian, A. (2007) Effects of probiotic and other feed additives on performance and immune response of broiler chicks. Int. Poult. Sci., 6(4): 261-265. 
5. Shareef, A.M. and Al-Dabbagh, A.S. (2009) Effect probiotic (Saccharomyces cerevisiae) on performance of broiler chicks. Iraqi J. Vet. Sci., 23(1): 23-29.

6. Getachew, T. (2016) A review on effects of probiotic supplementation in poultry performance and cholesterol levels of egg and meat. J. World Poult. Res., 6(1): 31-36.

7. Lokapirnasari, W.P., Rahmawati, A. and Eliyani, H. (2016) Potential addition of Lactobacillus casei and Lactobacillus rhamnosus lactic acid bacteria to feed consumption and feed conversion of broiler. J. Agro Vet., 5(1): 43-49.

8. Lokapirnasari, W.P., Sahidu, A.M., Soepranianondo, K., Supriyanto, A., Yulianto, A.B. and Al Arif, A. (2018) Potency of lactic acid bacteria isolated from Balinese bovine (Bos sondaicus) intestinal waste from slaughterhouse to improve nutrient content of wheat pollard as animal feedstuff by fermentation process. Vet. World, 11(8): 1127-1134.

9. Chichlowski, M., Croom, J., McBride, B.W., Daniel, L., Davis, G. and Koci, M.D. (2007) Direct-fed microbial primalac and salinomycin modulate whole-body and intestinal oxygen consumption and intestinal mucosal cytokine production in the broiler chick. Poult. Sci., 86(6): 1100-1106.

10. Forte, C., Acuti, G., Manuali, E., Proietti, P.C., Pavone, S., Trabalza-Marinucci, M., Moscati,L., Onofri,A., Lorenzetti, C. and Franciosini, M.P. (2016) Effects of two different probiotics on microflora, morphology, and morphometry of gut in organic laying hens. Poult. Sci., 95(11): 2528-2535.

11. Abdelqader, A., Al-Fataftah, A.R. and Daş, G. (2013) Effects of dietary Bacillus subtilis and inulin supplementation on performance, eggshell quality, intestinal morphology and microflora composition of laying hens in the late phase of production. Anim. Feed Sci. Technol., 179(1-4): 103-111.

12. Knap, I., Kehlet, A.B., Bennedsen, M., Mathis, G.F., Hofacre, C.L., Lumpkins, B.S., Jensen, M.M., Raun, M. and Lay, A. (2011) Bacillus subtilis (DSM17299) significantly reduces Salmonella in broilers. Poult. Sci., 90(8): 1690-1694.

13. Jeong, J.S. and Kim, I.H. (2014) Effect of Bacillus subtilis C-3102 spores as a probiotic feed supplement on growth performance, noxious gas emission, and intestinal microflora in broilers. Poult. Sci., 93(12): 3097-3103.

14. Li, S.P., Zhao, X.J. and Wang, J.Y. (2009) Synergy of Astragalus polysaccharides and probiotics (Lactobacillus and Bacillus cereus) on immunity and intestinal microbiota in chicks. Poult. Sci., 88(3): 519-525.

15. Watkins, B.A., Miller, B.F. and Neil, D.H. (1982) In vivo inhibitory effects of Lactobacillus acidophilus against pathogenic Escherichia coli in gnotobiotic chicks. Poult. Sci., 61(7): 1298-1308.

16. Pambuka, S.R., Sjofjan, O. and Radiati, L.E. (2014) Effect of liquid probiotics mixed culture supplements through drinking water on laying hens performance and yolk cholesterol. J. Worlds Poult. Res., 4(1): 5-9.

17. Nahashon, S.N., Nakaue, H.S. and Mirosh, L.W. (1996) Performance of single comb white leghorn fed a diet supplemented with a live microbial during the growth and egg laying phases. Anim. Feed Sci. Technol., 57(1-2): 25-38.

18. Yousefi, M. and Karkoodi, K. (2007) Effect of probiotic thepax ${ }^{\circledR}$ and Saccharomyces cerevisiae supplementation on performance and egg quality of laying hens. Int. J. Poult. Sci., 6(1): 52-54.

19. Mahdavi, A.H., Rahman, H.R. and Pourreza, J. (2005) Effect of probiotic supplements on egg quality and laying hen's performance. Int. J. Poult. Sci., 4(7): 488-492.

20. Ramasamy, K., Abdullah, N., Wong, M.C., Karuthan, C. and Ho, Y.W. (2010) Bile salt deconjugation and cholesterol removal from media by Lactobacillus strains used as probiotics in chickens. J. Sci. Food Agric., 90(1): 65-69.

21. Richards, M.P. (2003) Genetic regulation of feed intake and energy balance in poultry. Poult. Sci., 82(6): 907-916.

22. Lindholm-Perry, A.K., Sexten, A.K., Kuehn, L.A., Smith, T.P., King, D.A., Shackelford, S.D., Wheeler, T.L., Ferrell, C.L., Jenkins, T.G., Snelling, W.M. and Freetly, H.C. (2011) Association, effects and validation of polymorphisms within the NCAPG-LCORL locus located on BTA6 with feed intake, gain, meat and carcass traits in beef cattle. BMC Genet., 12(1): 103.

23. Wolc, A., Arango, J., Settar, P., Fulton, J.E., O'sullivan, N.P., Preisinger, R., Habier, D., Fernando, R., Garrick, D.J., Hill, W.G. and Dekkers, J.C.M. (2012) Genome-wide association analysis and genetic architecture of egg weight and egg uniformity in layer chickens. Anim. Genet., 43(1): 87-96.

24. Edens, F.W. (2003) An alternative for antibiotic Se in poultry: Probiotics. Rev. Bras. Ciênc. Avic., 5(2): 75-97.

25. Daneshyar, M., Kermanshahi, H. and Golian, A. (2009) Changes of biochemical parameters and enzyme activities in broiler chickens with cold-induced ascites. Poult. Sci., 88(1): 106-110.

26. Davis, G.S. and Anderson, K.E. (2002) The effects of feeding the direct-fed microbial, primalac, on growth parameters and egg production in single white leghorn hens. Poult. Sci., 81(6): 755-759.

27. Khan, S.H., Atif, M., Mukhtar, N., Rehman, A. and Fareed, G. (2011) Effects of supplementation of multi-enzyme and multi-species probiotic on production performance, egg quality, cholesterol level and immune system in laying hens. J. Appl. Anim. Res., 39(4): 386-398.

28. Inatomi, T. (2016) Laying performance, immunity and digestive health of layer chickens fed diets containing a combination of three probiotics. Sci. Postprint, 1(2): e00058.

29. Yan, W., Sun, C., Yuan, J. and Yang, N. (2017) Gut metagenomic analysis reveals prominent roles of Lactobacillus and cecal microbiota in chicken feed efficiency. Sci. Rep., 7(3): 45308.

30. Yörük, M.A., Gül, M., Hayirli, A. and Macit, M. (2004) The effects of supplementation of humate and probiotic on egg production and quality parameters during the late laying period in hens. Poult. Sci., 83(1): 84-88.

31. Chen, Y.C., Nakthong, C. and Chen, T.C. (2005) Improvement of laying hen performance by dietary prebiotic chicory oligofructose and inulin. Int. J. Poult. Sci., 4(2): 103-108.

32. Stanley, D., Geier, M.S., Denman, S.E., Haring, V.R., Crowley, T.M., Hughes, R.J. and Moore, R.J. (2013) Identification of chicken intestinal microbiota correlated with the efficiency of energy extraction from feed. Vet. Microbiol., 164(1-2): 85-92.

33. Turnbaugh, P.J., Bäckhed, F., Fulton, L. and Gordon, J.I. (2008) Diet-induced obesity is linked to marked but reversible alterations in the mouse distal gut microbiome. Cell Host Microbe, 3(4): 213-223.

34. Haddadin, M.S.Y., Abdulrahim, S.M., Hashlamoun, E.A.R. and Robinson, R.K. (1996) The effect of Lactobacillus acidophilus on the production and chemical composition of hen's eggs. Poult. Sci., 75(4): 491-494.

35. Lokapirnasari, W.P., Dewi, A.R., Fathinah, A., Hidanah, S., Harijani, N., Soeharsono, S., Karimah, B. and Andriani, A.D. (2017) Effect of probiotic supplementation on organic feed to alternative antibiotic growth promoter on production performance and economics analysis of quail. Vet. World, 10(12): 1508-1514.

36. Panda, A.K., Reddy, M.R., Rao, S.V.R. and Praharaj, N.K. (2003) Production performance, serum/yolk cholesterol and immune competence of white leghorn layers as influenced by dietary supplementation with probiotic. Trop. Anim. Health Prod., 35(1): 85-94. 